\title{
Studying the Role of Media in the Diffusion of English Words Into the Kashmiri Language: A Linguistic Overview
}

\author{
Nisar Ahmad Koka \\ Department of English, Faculty of Languages and Translation, King Khalid University, Abha, KSA \\ Mohammad Nurul Islam \\ Department of English, Faculty of Languages and Translation, King Khalid University, Abha, KSA \\ Mohammad Osman Abdul Wahab \\ Department of English, Faculty of Languages and Translation, King Khalid University, Abha, KSA
}

Javed Ahmad

English Language Center (ELC) Graiger, Faculty of Languages and Translation, King Khalid University, Abha, KSA

\begin{abstract}
Studying the predominant occurrence and existence of English lexicon in other languages in contact with English has emerged out to be of immense interest among the researchers of sociolinguistics and theoretical linguistics. The present study is devoted to demonstrate various English-Kashmiri language contact situations and the subsequent diffusion/ flow of English words into the Kashmiri language. The study attempts to explore the significant role of media in its different forms in enhancing and determining the transport of English words into the speech of Kashmiri speakers. The study seeks to address the motivation and inspiration of Kashmiri speakers behind the English-Kashmiri linguistic shift, and the influence of the prevailing circumstances on this English-Kashmiri linguistic diffusion. The liberality of the English language in handing over such an enormously huge amount of word treasure to the Kashmiri language, and the receptivity of the Kashmiri language in accepting this vocabulary treasure from English at a very large scale has been thrown light on in the study. In the present study, an attempt has been made to display a comprehensive list of English words used in various domains of social life of the Kashmiri speech community.
\end{abstract}

Index Terms - export, import, language contact, linguistic diffusion, Print and electronic media, naturalization

\section{INTRODUCTION}

Linguistic amalgamation and subsequent diffusion/transport of words from one linguistic system into another is a direct outcome of language contact situation in an atmosphere of inter-lingual communication setup. When two or more languages serve different purposes in a particular social situation, they develop in an envelope of 'import' and 'export' of lexicon among themselves. The alternation and exchange of linguistic items among these languages becomes an inventive and fertile phenomenon in that situation. This process of transfer of linguistic stock from one linguistic system into another is supposed occur at any time during the course of contact the languages are in (Koka, 2015, p. 2). According to Einar Haugen (1950, p. 212) borrowing is "the attempted reproduction in one language patterns previously found in another". The most frequently encountered product and observable outcome of the cultural contact is the set of loanwords imported into the linguistic system of each language involved (Haugen 1950, p. 22 cited in Koka, 2015, p. 2).

B.L.Hoffer (2002, cited in Koka, 2015, p. 3), states that studying loanwords carefully provides an interesting insight into the history of cultures across the world. In the broadest terms, classical Chinese, Sanskrit, Arabic, Greek and Latin were the five languages that have had an overwhelming significance as carriers of culture. Bloomfield (Bloomfield, 1933, cited in Koka, 2015, p. 3), pointed out that for adults the degree of control of the other language affects the borrowing. He argues that people who know another language well can use the items from the other language at will. On the other hand, people who read the foreign forms, as opposed to learning them in conversation, interpret the foreign orthography in native terms. (Hoffer, 2002). Thus, in English "Mexico" (Spanish [mexiko]) became [meksiko] and "Don Quixote" (Spanish [don kixote]) became [dankwIksat], as in "quixotic," which is given [kwlksatlk] as the dictionary pronunciation.

\section{A. Factors Influencing/Determining the Linguistic Diffusion/Transport}

Researchers and experts in the areas of sociolinguistics and cultural anthropology have discovered and documented various factors determining /influencing the amount and rate of linguistic diffusion which involves both import and 
export of word stock among the languages in contact. Koka (2016), states that, in Europe and other countries, the languages in a close contact over centuries have resulted in extensive transfer of words from one linguistic system to another. Language and cultural contact has been intensified by the introduction and use of the modern communication tools such as radio, television, smartphones, mobile phones, iPhones, ipads, tablets etc.by the spread and exchange of huge amount of linguistic stock. Koka (2016, p. 3), mentions that the globalization of markets for products across the globe has brought about a wide range of advertisements which along with assigning the foreign names have assigned the foreign terms to these products. Another reason which has resulted in the diffusion and transfer of linguistic stock across the languages at a larger scale has been air travel.

Several scholars have identified different language contact situations which impact the process of exchange of linguistic items among the languages in contact. Commerce or incidental contact has been found to bring about relatively little diffusion, whereas side-by-side contact over decades or centuries, as in case of the Scandinavians in England, has resulted in diffusion of words at a large scale. Dominance of one linguistic system over the other, such as the French in England after 1066, usually has a one-way effect over time. Contact with a prestigious language, whether there are numbers of speakers in contact or not, often results in borrowing by the educated classes, which in turn may or may not diffuse the words through the general vocabulary. Latin phrases are still used in scholarly publications in the West, centuries after Latin was no longer anyone's native language. Edward Sapir (Sapir, 1921, cited in Koka, 2016 , p. 3), states, how Chinese flooded Korean and Japanese with vocabulary and how English borrowed an immense number of words and productive affixes from French.

According to Robert Fine and Sam Feist (2006), the social networks are found to be flourished and developed by the use of existing tools of electronic social media, such as Facebook, Twitter, WhatsApp instant messaging systems etc. These tools have an excellent capability to intensify community involvement and participation of masses at a very large scale. Social media sites have undergone a remarkable shift to strengthen bifacial or multiracial communication in recent years (Allyn and Bacon, 2009). These sites exhibit probabilities and feasibilities for health education messaging that have yet to be completely registered, ascertained and recognized. In addition, they provide new marketplaces to ease the process of conversation, involving an extensively huge section of people. Different social media channels and devices have extraordinarily contributed to laying out of some modern techniques for commissioning fairly a large group of masses which in different circumstances was very difficult to be touched on with such closeness. (Dozier et al., 2011)

According to O'Connor (2014), presently, a fairly vast amount of vernacular communication is carried out in written form and disseminated and transmitted by modern technological devices such as smartphones and so many other social media mechanisms. It has been made obligatory for a written language to modify and adjust itself in accordance with the requirements of existing simultaneous communication, giving rise to new forms and terms for use at a very large scale. The allocation of the existing vocabulary is one of the most potential ways that makes social media to influence the English language. Vocabulary items with existing meanings have now been assigned different meanings in the social media context, which is finally reflected in oral mode of communication too. With an advancement and momentum in the use of internet, the English language has assumed a very significant role in the transmission of technology. Since the Americans are credited for inventing the internet, the entire vocabulary used on internet and other forums of technology is exclusively disseminated and spread in English because no other options were available to carry on the process of communication when the technology was flourishing (O' Conner, 2014).

\section{B. Role of Media in the Diffusion/ Transport of English Lexicon into Kashmiri}

Media is one of the most powerful and potential sources of the existing linguistic scenario in the valley of Kashmir. It has largely confirmed the existing linguistic norms as well as well as linguistic attitudes of Kashmiri people irrespective of their age group and educational background. It is the media in its different forms which has played a very prominent role in enhancing the social significance of the English language in the Kashmiri speech community. English has created its space not only in social setup of Kashmiri speech community, but in the psychological resilience of every individual Kashmiri speaker. When we look at the electronic media, the introduction of the cable network, DTH and other latest network systems, people are found more comfortably accessible to English channels. With the advent and emergence of this growing interest in English, the indigenous media channels have almost been pushed to the negligence. It is a common belief among the people of all age groups that learning English is a precondition for the betterment of life. The prestige of English fluency is encouraged by parents and eagerly accepted by children within and outside their peer group domain.

World's top English news channels disseminating events via the medium of television have emerged out as household names in Kashmir. These news channels include: BBC World News, Fox News Channel (FNC), Cable News Network (CNN), Sky News, MSNBC, Al-Jazeer/Jazeera Satellite Channel (JSC), Euro-news, Geo News, NDTV India (English), Star Plus, Star Movies, HBO, Voice of Germany etc. Times and Newsweek are considered as dignity and status symbol. The advent of electronic gadgets- laptops, iPods, iPads, tablets, smartphones, computers and social networking sites have extraordinarily contributed to the increasing amount of switched and mixed speech among Kashmiri people. The growing influence of English has also brought about a shift in the language for counting, naming the colors, naming days of the week and months of the year. Presently, English is predominantly used in Kashmir, and the educated sect of youth finds it difficult to use their mother tongue exclusively in various domains of their social life. 
The expertise with which the Kashmiri speakers alternate with English has become quite a normal mode of communication in accordance with existing patterns in electronic media.

Print media equally presents an interesting picture of this increasing influence of English on Kashmiri speakers with more and more people preferring English newspapers. Visiting the world-class Time magazine and online newspaper sites especially those of Washington Times, New York Times, and The Economist etc. has become the routine for Kashmiri educated youth. Print media in Kashmir operates in the form of Urdu and English daily and weekly newspapers. A continuous increase in the number of English newspapers surely points to a particular linguistic scenario where a prestige language is expanding its impact range of usage at a constant speed. Till mid 90s only one daily newspaper was published from Kashmir in English, but since 1995 onwards there has been a continuous increase in the production of English newspapers. At present, about as many as 15 English newspapers are published in Kashmiri which accounts for 15 fold increase in the number of English newspapers published in Kashmir in the recent past. Similarly, only one weekly English newspaper was published in Kashmir in mid 90s, but this number is also found to have risen to 12 .

\section{Linguistic Implications of English-Kashmiri Linguistic Diffusion/Transport}

Koka (2016) confirms that upon finding the imported words in accordance with its own structure and temperament, the importing language accepts them with certain changes and modifications to expand and enrich its source of vocabulary. Since language is a complex system of systems and sub-systems, every sub-system has its own peculiar principles and patterns, which are dependent on the overall grammatical system of the language. In a language, words and expressions are formed and structured in accordance with the phonetic and morphemic principles of that language. When it imports linguistic items from other languages, these items are accepted and adapted according to these principles. Under its tremendous influence, a language naturalizes and nativizes certain sounds which make it possible for a large number of words to make their way into the importing language (Koka, 2016, p. 5).

English has ceased to be an "English language" in the sense of belonging only to the people who are ethnically English. Use of English is growing country-by-country internally and world-wide for international communication. Most people learn English for practical rather than ideological reasons. Modern English, sometimes described as the first global lingua franca, is also regarded as the first world language. Since English is the world's most widely used language in information technology, newspaper publishing, book publishing, international telecommunications, scientific publishing, international trade, mass entertainment, and diplomacy, Kashmiri speakers use a large number of English words during their intra group oral communication. Although, the number of these words is extremely large, they do not use many of them in their original form. Most of these words have experienced different changes according to phonological and phonetic build-up of the Kashmiri language. Kashmiri speakers are found to modify and nativise these imported English words according to the phonetic temperament of their mother tongue.

\section{REVIEW OF THE RELATED LITERATURE}

Einar Haugen's “the Analysis of linguistic borrowing” (1950) is generally regarded as a major reference point in the field of borrowing. The work summarizes and extends previous research and forms basis for the much of the later research in this direction. Haugen's (1950, p. 210) goal was to "define more precisely the terminology used in linguistic analysis of borrowing and to setup certain hypotheses concerning the process of borrowing" (Haugen, 1950, p. 210 cited in Koka, 2015.p. 4). Uriel Weinreich's Languages in Contact (Weinreich, 1953, p. 1, cited in Koka, 2015, p. 4), was the pivotal work on the study of impact of one language on other languages. The bibliography of 658 titles covered the field from its beginning to early 1950s. He treated borrowings under the topic / subject of bilingualism and as an example, at first, as that of interference, or "deviation from the norms of either language". Winfred, P. Lehman's Historical Linguistics: an introduction (1962), the chapter devoted to borrowing offers some suggestions for further study in areas not yet adequately explored. One of these areas which demand more research is that of Pidgins. Pidgins are specially created to serve communication among people from two or more different language speaking communities on a very simple level. Phonological and morphological systems are often stripped to essentials and words from both languages are borrowed into the new "system" (Lehman, 1962, cited in Koka, 2015, p. 4). The sophisticated work of William Labov (1966 cited in Koka, 2015, p.4) has directed research towards the rigor suggested by Lehmann. Historical linguistics continues to develop the study of borrowing, especially the theoretical bases of linguistics.

According to Heller (1988, p.15 cited in Koka, 2015, p.4), since 1950 many attempts have been made to find a diagnostic criteria which will distinguish among borrowing, transfer, interference, code switching, code mixing and language acquisition. Scotton (1988, p.160 cited in Koka, 2015, p. 4), uses the level of social significance of the item as one of the approaches to distinguish borrowing from code switching. He claims that if the non-native items carry social significance, it is considered as code switching. Poplack (1988, p. 220 cited in Koka, 2015, p. 4), suggests that the use of a borrowed item continues to be code switching until enough speakers use it and is accepted by a vast majority of native speakers into their dictionary.

As a matter of fact, language use in the world's entire cutlers is accompanied by movements of the speaker and addressee. Generally speaking, non-verbal communication deals with the non-language features of communication. According to Hall (1977 cited in Koka, 2015, p .4), the field covers gestures, gaze behavior, proxemics (the study of 
distracting), hepatics (touching behavior), and many more. Hall (1977) further admits that in a language contact situation, some or all of these non-verbal features of one group may be borrowed by the other group in contact. This study of borrowing in non-verbal communication covers not only the items such as gestures, but also the effects of the misuse of every other's nonverbal features on cross-cultural or the cross-group communication.

The borrowing of non-verbal features and using them inappropriately in relation to a particular social context may cause a reaction which is much more powerful, and rather dangerous than the misuse of a loanword. The study of touching behavior shows that some groups react powerfully and rather aggressively to touching behavior by a member who is not considered to be a part of their group. Hoffer, B.L. (1997 cited in Koka, 2015, p. 4), admits that the touching of one's arm during conversation may be considered as repulsive or even immoral.

\section{Methodology}

\section{A. Research Hypotheses}

For the present study, following hypotheses have to be verified and proved:

i. Language contact situation is a prerequisite for linguistic diffusion.

ii. Vocabulary of a language is a reliable source for analyzing the range of imported words and the extent of linguistic diffusion in a language.

iii. Cultural synthesis and the process of linguistic amalgamation influence the linguistic scenario of speech communities in contact.

\section{B. Objective of the Study}

Koka, (2015, p. 5), admits that Kashmiri speech community offers an excellent example of English-Kashmiri language contact situation. This language contact situation provides basis for the linguistic amalgamation and thereby paving a path for the transfer of linguistic items from English into Kashmiri at a very large scale. The main objective of this study is to find out as to how, to what extent and in what circumstances/situations as well as how frequently Kashmiri speakers use English words in various domains of their social life.

The present study follows the same pattern of the research methodology as adopted by other scholars of sociolinguistics while carrying out similar sociolinguistic investigations. The study is purely data oriented, and the entire data has been collected as discussed below:

\section{Data Collection}

To elicit the desired data for the present study as natural as possible, we used the same techniques and tools of data collection as used in one of the main investigator's previous studies (Koka, 2015, p. 5). Since the main investigator of the present study being a native speaker of Kashmiri, for the present study the main tool for collecting the data has been his close and minute observation regarding the use of language by Kashmiri speakers in various domains of their social life. So far as the places of data collection for the present study are concerned, they have also been the same as in one of the investigator's previous studies (Koka, 2015, p. 5).These places mainly include: parks, gardens, tourist spots, hostels, schools, colleges, bus stops, markets, paddy fields, orchards, government offices, hospitals, exhibition grounds, and other similar places. These places were chosen keeping in view the situations where the frequency of occurrence of English words in the speech of Kashmiri speakers was relatively higher. As mentioned earlier, the main investigator of the present study being a native speaker of Kashmiri also visited many villages, towns, urban centers, and some other common meeting places, where the people of the Kashmiri speech community were easily available and had oral communication related to the matters of day-to-day life. The investigator also recorded the speech of various professional people while dealing with the concerned people. Moreover, the investigator very carefully observed Kashmiri speakers during their telephonic/cell phonic conversations with each other and with the speakers of other languages and recorded their speech in a quite natural way (Koka, 2015, p. 5).

\section{Editing of the Data}

Since the entire mass of the data collected was not useful for the purpose of the present study, the irrelevant, weak, unwanted and doubtful portions of the data were weeded out and eliminated. In the process of editing, the weaknesses found in the data were rectified and made useful for the purpose.

\section{E. Data Analysis}

With a view to arriving at the right conclusion and desired results, only the desired portion of the data was analyzed to be used for the purpose. This was done in accordance with the verification of the proposed hypotheses of the present study. Since the tabulation of data facilitated its understanding and simplified its process of study, the resultant available portion of data was tabulated for interpretation.

\section{RESULTS AND ANALYSIS}

\section{Kashmiri-English Language contact situation and Linguistic amalgamation}

Two or more languages are said to be in contact if they are used alternatively by the same speakers. Language contact 
situation is a prerequisite and precondition for linguistic borrowing. When two or more languages exist side by side and serve various purposes in a particular speech community, import and export of linguistic items among these languages becomes a prominent feature of that sociolinguistic setup (Koka, 2015).

Being a very prestigious language among Kashmiri speakers, English has emerged out to be a significant contact language among them. Since it is the main source of carrying out all official functions in the Kashmiri speech community, its speakers are bound to learn and use it. As the language of the wider communication and because of its vital role in various domains of Kashmiri speech community, English enjoys a very special status in the valley of Kashmir. Being a language of vital role among Kashmiri speakers, English has especially been very cordial, cooperative and friendly in donating a very huge stock of vocabulary to Kashmiri. Kashmiri speakers in response have equally been found to be very hospitable to receive this word stock and use it in their oral communication at a large scale particularly

The socio-psychological attitudes of the Kashmiri people have been found to be potentially influenced by English in a very effective manner. In the valley of Kashmir, the English Language has gained a very high prestige, and this prestige can be observed in a number of ways. In the past, it was only the domain of education where English had acquired a special status, but since the last two decades, English has vastly made its entrance into almost every domain of the Kashmiri speech community, and its use in different domains has increased considerably.

English is taught as a compulsory subject in all government, semi-government and private schools (from $1^{\text {st }}$.primary to the intermediate level) of the state education system (Koka, 2015, p.7).It is also taught as an optional subject at graduate and postgraduate levels of state education system (Koka, 2015, p.7). There are full-fledged postgraduate departments of English in the University of Kashmir and in all other universities of the state which produce quite a good number of postgraduate students and PhD scholars in English every year. Consequently, there has been noticed a higher percentage of bilingualism among Kashmiri mother tongue speakers with English. Another reason for the higher incidence of Kashmiri-English bilingualism lies in the fact that quite a considerable number of average educated Kashmiri speakers have a workable access to written and spoken mode of English.

The flow of English words into Kashmiri has been so massive that the range of their occurrence has dominated and flooded each and every essential domain of social life of the Kashmiri speech community such as administration, medicine, information technology, education, language and literature, legal law and the domain of daily conversation. It is worth mentioning that the immense export of English lexicon into Kashmiri has become such an essential need that no socio-cultural domain of the Kashmiri speech community could afford to be an exception to its import.

The following is a comprehensible sample of words of the English origin used in different socio-cultural domains of Kashmiri speech community. It should be pointed out that these words have been listed on the basis of the extent of inflow of English lexicon into the Kashmiri language, and their impact on the phonetic design of the Kashmiri language. However, it is worth mentioning that during the course of usage the words of English origin, a considerable portion these words has been found to be modified and naturalized by Kashmiri speakers in accordance with the phonetic design of their mother tongue, and quite a good number of these word have been found to have retained their original form.

\section{Words Used in Various Domains of Social Life of the Kashmiri Speakers}

\section{A. Words Used in the Domain of Administration}

Although Urdu is the official language of Jammu and Kashmir, it is rapidly found to be replaced by English. On the one hand, Urdu is predominantly used to maintain court and revenue records, on the other hand, on account of the extensive use of English by the younger educated generation who find themselves more comfortable in English than Urdu, there has been a remarkable shift in the trend to use Urdu. At present, almost all written representations and formal applications in administrative offices are encouraged in English both by the applicants as well as the recipients of these applications. Kashmiri speakers are found abundantly using English words for the concepts related to the administrative domain. It is to be pointed out that Kashmir speakers have modified and naturalized a large number of these words under the tremendous influence of their mother tongue pull. 
TABLE 1

WORDS USED IN THE DOMAIN OF ADMINISTRATION

\begin{tabular}{|c|c|c|}
\hline Word of English origin & Naturalized in Kashmiri & Gloss \\
\hline 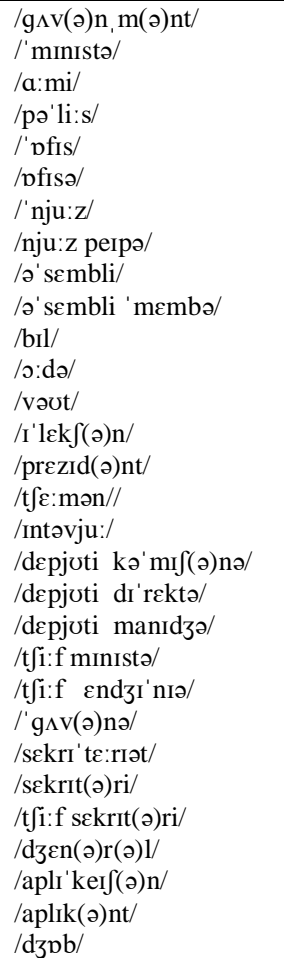 & $\begin{array}{l}\text { /gormnaTh/ } \\
\text { /məniŠtar/ } \\
\text { /armi:/ } \\
\text { /ptli: ə/ } \\
\text { /a:phis/ } \\
\text { /aphsar/ } \\
\text { /nivəz/ } \\
\text { /niviz pe:par/ } \\
\text { /esambali:/ } \\
\text { /esambali: member/ } \\
\text { /bil/ } \\
\text { /a:Dar/ } \\
\text { /voT/ } \\
\text { /alekŠən/ } \\
\text { /če:rme:n/ } \\
\text { /inTarvu:/ } \\
\text { /DipTi: kəmiŠnar/ } \\
\text { /DipTi: DarekTar/ } \\
\text { /DipTi: mane:jar/ } \\
\text { /či:ph məniŠtar/ } \\
\text { /či:ph inji:nar/ } \\
\text { /gavarnar/ } \\
\text { /sekTre:T/ } \\
\text { /sektori:/ } \\
\text { /či:ph sekTəri:/ } \\
\text { /janral sekTəri:/ } \\
\text { /aplike: Šan/ } \\
\text { /aplikanT/ } \\
\text { /ja:b/ }\end{array}$ & $\begin{array}{l}\text { Government } \\
\text { minister } \\
\text { army } \\
\text { police } \\
\text { office } \\
\text { officer } \\
\text { news } \\
\text { news paper } \\
\text { assembly } \\
\text { assembly member } \\
\text { bill } \\
\text { order } \\
\text { vote } \\
\text { election } \\
\text { president } \\
\text { chairman } \\
\text { interview } \\
\text { deputy commissioner } \\
\text { deputy director } \\
\text { deputy manager } \\
\text { chief minister } \\
\text { chief engineer } \\
\text { governor } \\
\text { secretariat } \\
\text { secretary } \\
\text { chief secretary } \\
\text { general secretary } \\
\text { application } \\
\text { applicant } \\
\text { job }\end{array}$ \\
\hline
\end{tabular}

\section{B. Words Used in the Domain of Medicine}

As a matter of fact, the domain of medicine is second to the domain of information technology in terms of using the huge volume of lexicon imported from English. This is because of the fact that the essential medical vocabulary/terminology is mostly readily available in English. Prescriptions, diagnoses and reports are totally written in English by doctors. The mode of conversation among the members of medical and paramedical staff is also full of English words. Moreover, even the common people are bound to use English words because of the non-availability of the exact equivalents and substitutes for these terms in Kashmiri. However, under the immense influence of their mother tongue, Kashmiri speakers tend to modify and nativise an enormous amount of these English words for the medical terminology and a huge amount of these words are found to retain the original form. 
TABLE 2

WORDS USED IN THE DOMAIN OF MEDICINE



\section{Words Used in the Domain of Information Technology}

Like many other speech communities, the Kashmiri speech community has overwhelmingly recognized and accepted English as the language of information technology. Almost 100 percent of technological terms used in Kashmiri are of the English origin when it applies to their spoken form. This is because of the fact that Kashmiri has till date not developed any substitutes and/or exact equivalents for these technical terms of its own. While using this imported technological terminology, Kashmiri speakers are found to use some of it in its original form, and modify and naturalize its huge volume under the tremendous influence of their mother tongue pull. 
TABLE 3

WORDS USED IN THE DOMAIN OF INFORMATION TECHNOLOGY

\begin{tabular}{|c|c|c|}
\hline Words of English origin & Naturalized in Kashmiri & Gloss \\
\hline /intənet/ & /inTarneT/ & Internet \\
\hline /Inpot/ & & input \\
\hline /Inst(ə)nt mesidz/ & & instant message \\
\hline sIkpn,' & & icon \\
\hline /Info' meif(ə)n/ & /inpha:rme:Šan/ & information \\
\hline /akses/ & & access \\
\hline /a'kaunt/ & & account \\
\hline /aplı'keIf(ə)n/ & & application \\
\hline$/ \mathrm{bak} \Lambda \mathrm{p} /$ & /be:kap/ & backup \\
\hline /blpg/ & /bla:g/ & blog \\
\hline /blu:tu: $\theta$ / & /blu:TUth/ & bluetooth \\
\hline /bravzə/ & /brovzar/ & browser \\
\hline /kamks:də/ & /ke:ka:Dar/ & camcorder \\
\hline /kam(ə)rə/ & /ke:mtra/ & camera \\
\hline /scl fəun/ & /selpho:n/ & cell phone \\
\hline /klık/ & /kilik/ & click \\
\hline /kəm'pju:tə/ & /kampu:Tar/ & computer \\
\hline /knnek'tiviti/ & & connectivity \\
\hline /kə:sə/ & /kərsar/ & cursor \\
\hline /kraj/ & /kre:ŠS/ & crash \\
\hline i:merl/ & & email \\
\hline /desktop/ & & desktop \\
\hline /di'spleI/ & /Disptle:/ & display \\
\hline /daun'ləod/ & & download \\
\hline /feIsbok/ & /phe:sbUk/ & face book \\
\hline /flppi/ & /phUla:pi:/ & floppy \\
\hline /f $\mathrm{f}_{\mathrm{II}} \mathrm{l} /$ & /phayil/ & file \\
\hline /hakə/ & /he:kar/ & hacker \\
\hline /ha:d dIsk/ & & hard disk \\
\hline /həum peidz/ & & homepage \\
\hline /dz^yk meil/ & & junk mail \\
\hline ki:bo:d/ & & keyboard \\
\hline /ki:pad/ & & keypad \\
\hline /laptop/ & & laptop \\
\hline /lpg In/ & & $\log$ in \\
\hline /log bf/ & & $\log$ off \\
\hline
\end{tabular}

\begin{tabular}{|c|c|c|}
\hline 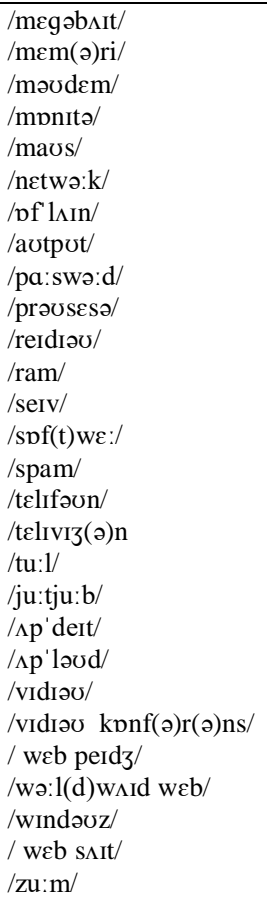 & $\begin{array}{l}\overline{\text { /memo:ri/ }} \\
\overline{\text { /ma:niTar/ }} \\
\overline{\text { /neTvərək/ }} \\
\overline{\overline{\text { /pra:sasar/ }}} \\
\overline{\text { /ra:m/ }} \\
\overline{\text { /sa:phtve:r/ }} \\
\text { /Te:le:pho:n/ } \\
\text { /Te:le:vijan/ } \\
\\
\\
\overline{\text { /vi:Dyo:ka:nphranəs/ }} \\
\text { /vərlD va:yiD veb/ }\end{array}$ & $\begin{array}{l}\text { Megabyte } \\
\text { memory } \\
\text { modem } \\
\text { monitor } \\
\text { mouse } \\
\text { network } \\
\text { offline } \\
\text { output } \\
\text { password } \\
\text { processor } \\
\text { radio } \\
\text { ram } \\
\text { save } \\
\text { software } \\
\text { spam } \\
\text { telephone } \\
\text { television } \\
\text { tool } \\
\text { you tube } \\
\text { update } \\
\text { upload } \\
\text { video } \\
\text { video conference } \\
\text { webpage } \\
\text { world wide web } \\
\text { windows } \\
\text { website } \\
\text { zoom }\end{array}$ \\
\hline
\end{tabular}

\section{Words used in the Domain of Education}

At present, English is the medium of education in all government, semi-government and privately run schools of the state education system. It is taught as a compulsory subject in all the aforementioned institutions (from $1^{\text {st }}$.primary to the intermediate level) of the state education set-up. It is also taught as an optional subject at graduate and postgraduate 
levels of education. There are full-fledged post graduate departments of English in the University of Kashmir and in all other universities of the state which produce quite a good number of post graduate students and research scholars in English every year. Consequent upon this, it has been noticed that there is a very high percentage of bilingualism in English among Kashmiri mother tongue speakers. Another reason for the higher incidence of Kashmiri -English bilingualism lies in the fact that quite a considerable number of average educated Kashmiri speakers have a workable access to written and spoken modes of English. Such a huge acquaintance of the people of Kashmir with English has resulted in an enormous transfer of English words into their speech. Some of the word stock imported by Kashmiri speakers from English is used in its original form and its huge amount has been found to be modified by Kashmiri speakers in accordance with the phonetic temperament of their mother tongue (Kashmiri).

TABLE 4

WORDS USED IN THE DOMAIN OF EDUCATION

\begin{tabular}{|c|c|c|}
\hline Words of English origin & Naturalized in Kashmiri & Gloss \\
\hline 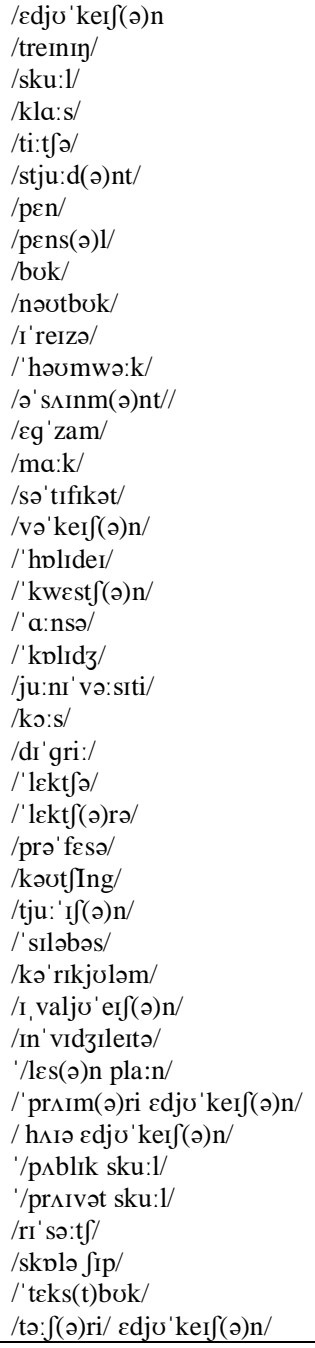 & $\begin{array}{l}\text { /ajUke:Šan/ } \\
\text { / Tre:ning/ } \\
\text { /so:ku:1/ } \\
\text { / kəla:s/ } \\
\text { /Ti:čar/ } \\
\text { / siTu:DanT/ } \\
\text { /pensal/ } \\
\\
\\
\text { / ho:mvərək/ } \\
\text { /ekza:m/ } \\
\text { /ma:rkts/ } \\
\text { /səTiphikeT/ } \\
\text { /vake:Šan/ } \\
\text { /holiDe:/ } \\
\text { /koasčan/ } \\
\text { /a:nsar/ } \\
\text { /ka:lej/ } \\
\text { /yu:nivarsi:Ti:/ } \\
\text { /ko:rəS/ } \\
\text { /Digri:/ } \\
\text { /lekčarar/ } \\
\text { /lekčarar/ } \\
\text { /prophesar/ } \\
\text { /ko:čing/ } \\
\text { /Tiv Šan/ } \\
\text { /selebas/ } \\
\text { /keri:kyu:lam/ } \\
\text { /iva:live:Šan/ } \\
\text { /invijile:Tar/ } \\
\text { /pre:mtri: ejUke: Šan/ } \\
\text { /hayer ejUke:Šan/ } \\
\text { /pablik so:ku:1/ } \\
\text { /preyve:Th so:ku:1/ } \\
\text { /risərəč/ } \\
\text { /sUka:larŠip/ } \\
\text { /TektTbUk/ } \\
\text { /TərŠrəri: ajUke:Šan/ } \\
\end{array}$ & $\begin{array}{l}\text { Education } \\
\text { training } \\
\text { school } \\
\text { class } \\
\text { teacher } \\
\text { student } \\
\text { pen } \\
\text { pencil } \\
\text { book } \\
\text { notebook } \\
\text { eraser } \\
\text { homework } \\
\text { assignment } \\
\text { exam } \\
\text { marks } \\
\text { certificate } \\
\text { vacation } \\
\text { holiday } \\
\text { question } \\
\text { answer } \\
\text { college } \\
\text { university } \\
\text { course } \\
\text { degree } \\
\text { lecture } \\
\text { lecturer } \\
\text { professor } \\
\text { coaching } \\
\text { tuition } \\
\text { syllabus } \\
\text { curriculum } \\
\text { evaluation } \\
\text { invigilator } \\
\text { lesson plan } \\
\text { primary education } \\
\text { higher education } \\
\text { public school } \\
\text { private school } \\
\text { research } \\
\text { scholarship } \\
\text { textbook } \\
\text { tertiary education }\end{array}$ \\
\hline
\end{tabular}

\section{E. Words Used in the Domain of Language and Literature}

It is again on account of very high intimacy of Kashmiri speakers with English, the domain of language and literature is found to be extraordinarily flooded with English lexicon. As far as the domain mentioned is concerned, a huge volume of English words infiltrated into the speech of Kashmiri speakers has been naturalized and nativized in Kashmiri, whereas, a considerable portion of this imported stock maintains its original form. 
TABLE 5

WORDS USED IN THE DOMAIN OF LANGUAGE AND LITERATURE

\begin{tabular}{|c|c|c|}
\hline Words of English origin & $\begin{array}{l}\text { Modified/Naturalized } \\
\text { Kashmiri }\end{array}$ & Gloss \\
\hline 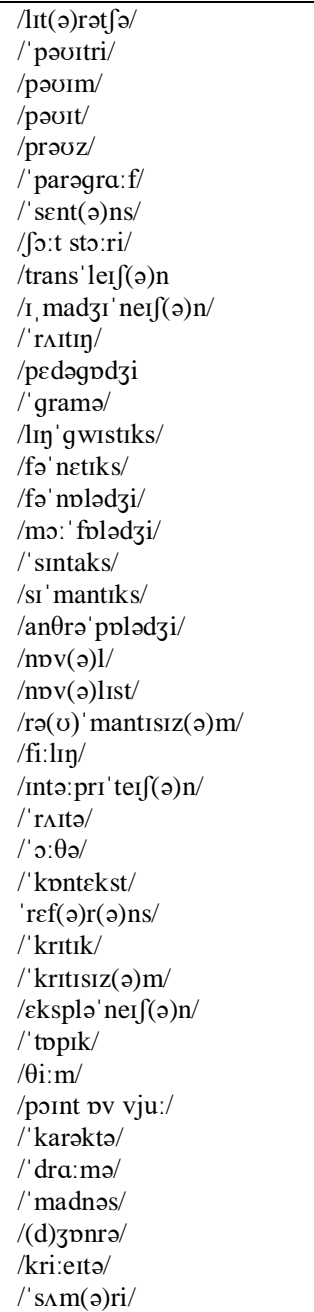 & $\begin{array}{l}\text { /liTre:čar/ } \\
\text { /poyTri:/ } \\
\text { /poyim/ } \\
\text { /poyiT/ } \\
\text { /paragra:ph/ } \\
\text { /senTents/ } \\
\text { /Ša:TsTori:/ } \\
\text { /Trantsle:Šan/ } \\
\text { /ime:jine:Šan/ } \\
\text { /peDaga:ji:/ } \\
\text { /gre:mar/ } \\
\text { /linvisTikts/ } \\
\text { /phonaTikts/ } \\
\text { /phona:ltji:/ } \\
\text { /ma:rpa:ltji:/ } \\
\text { /sinTe:kts/ } \\
\text { /sima:nTikts// } \\
\text { /enthro:pa:lji:/ } \\
\text { /na:val/ } \\
\\
\text { /phi:lin/ } \\
\text { /inTarpreTe:Šan/ } \\
\text { /ryTar/ } \\
\text { /a:thar/ } \\
\text { /rephrants/ } \\
\text { /ja:Dnar/ } \\
\text { /kriye:Tar/ } \\
\text { /samari:/ } \\
\text { /thi:m/ } \\
\text { /poyinT of viv/ } \\
\text { /DarekTar/ } \\
\text { /me:ma:/ } \\
\end{array}$ & $\begin{array}{l}\text { Literature } \\
\text { poetry } \\
\text { poem } \\
\text { poet } \\
\text { prose } \\
\text { paragraph } \\
\text { sentence } \\
\text { short story } \\
\text { translation } \\
\text { imagination } \\
\text { writing } \\
\text { pedagogy } \\
\text { grammar } \\
\text { linguistics } \\
\text { phonetics } \\
\text { phonology } \\
\text { morphology } \\
\text { syntax } \\
\text { semantics } \\
\text { anthropology } \\
\text { novel } \\
\text { novelist } \\
\text { romanticism } \\
\text { feeling } \\
\text { interpretation } \\
\text { writer } \\
\text { author } \\
\text { context } \\
\text { reference } \\
\text { critic } \\
\text { criticism } \\
\text { explanation } \\
\text { topic } \\
\text { theme } \\
\text { point of view } \\
\text { character } \\
\text { drama } \\
\text { madness } \\
\text { genre } \\
\text { creator } \\
\text { summary }\end{array}$ \\
\hline
\end{tabular}

\section{F. Words Used in the Domain of Legal Law}

Urdu was used to maintain all revenue and court records in the recent past. For the last two decades there has been a shift with regard to the use of Urdu as far as its use as a court language is concerned. A considerable replacement of Urdu by English has been observed at a very large scale for the last few years. In the domain of legal law, a bulk stock of English words has been found to make its way into the speech of Kashmiri speakers. Kashmiri speakers are found to use a major portion of these terminologies of legal law imported from English in its original form, and its considerable amount is modified and naturalized under the tremendous influence of their mother tongue. 
TABLE 6

WORDS USED IN THE DOMAIN OF LEGAL LAW

\begin{tabular}{|c|c|c|}
\hline Words of English origin & Naturalized in Kashmiri & Gloss \\
\hline 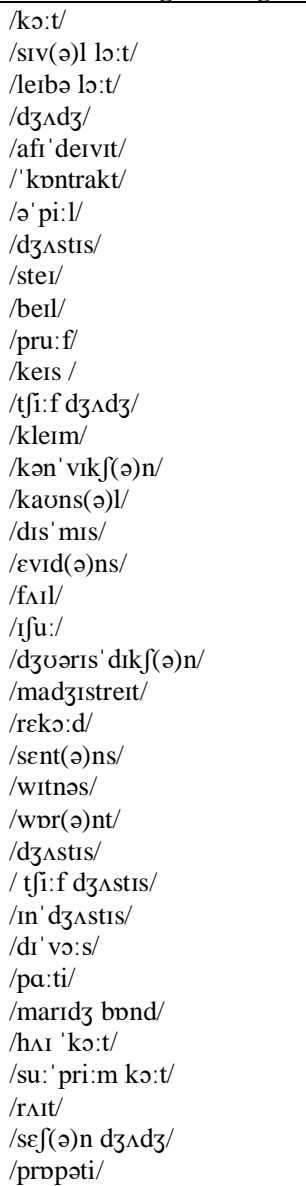 & 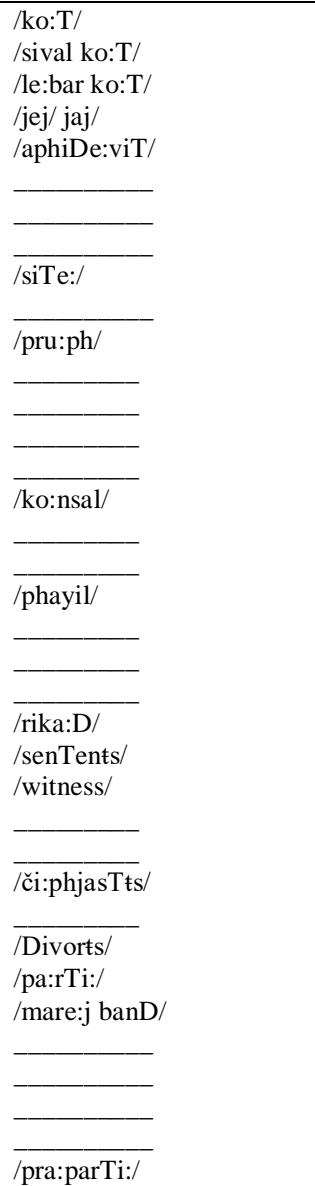 & $\begin{array}{l}\text { Court } \\
\text { civil court } \\
\text { labor court } \\
\text { judge } \\
\text { affidavit } \\
\text { contract } \\
\text { appeal } \\
\text { justice } \\
\text { stay } \\
\text { bail } \\
\text { proof } \\
\text { case } \\
\text { chief judge } \\
\text { claim } \\
\text { conviction } \\
\text { counsel } \\
\text { dismiss } \\
\text { evidence } \\
\text { file } \\
\text { issue } \\
\text { jurisdiction } \\
\text { magistrate } \\
\text { record } \\
\text { sentence } \\
\text { witness } \\
\text { warrant } \\
\text { justice } \\
\text { chief justice } \\
\text { injustice } \\
\text { divorce } \\
\text { party } \\
\text { marriage bond } \\
\text { high court } \\
\text { supreme court } \\
\text { right } \\
\text { session judge } \\
\text { property }\end{array}$ \\
\hline
\end{tabular}

\section{G. Words Used in the Domain of Daily Conversation}

Like other domains, Kashmiri speakers use a huge number of English words haphazardly and randomly in the domain of their daily conversation. This enormous amount of English lexicon has been incorporated into the domain of daily speech of the Kashmiri speakers in both formal and informal forms of the language. The Kashmiri speakers tend to maintain the originality of certain amount of this imported vocabulary stock from English while using it in the domain of their daily conversation as well as modify and nativize an extensive portion of it in accordance with the phonetic influence of their mother tongue. 
TABLE 7

WORDS USED IN THE DOMAIN OF DAILY CONVERSATION OF KASHMIRI SPEAKERS

\begin{tabular}{|c|c|c|}
\hline Words of English origin & Naturalized in Kashmiri & Gloss \\
\hline /aksid(ə)nt/ & /eksiDanT/ & accident \\
\hline /f & /phyriin/ & firing \\
\hline /عn'kauntə/ & lenka: vTar/ & encounter \\
\hline /krakdaon/ & /kre:kDavn/ & crackdown \\
\hline /lokdaun/ & /la:kDavtn/ & lockdown \\
\hline /ə'gri:m(ə)nt/ & /agri:minaTh/ & agreement \\
\hline /mi:try/ & /miTirn/ & meeting \\
\hline /I'lekf(ə)n/ & /elekŠan/ & election \\
\hline /si:z(ə)n/ & & season \\
\hline $\begin{array}{l}\text { /eksəsıIz/ } \\
\text { /scntə/ }\end{array}$ & /ekzarsayiz/ & exercise \\
\hline $\begin{array}{l}\text { /scntə/ } \\
\text { /baund(ə)ri/ }\end{array}$ & /senTar/ & $\begin{array}{l}\text { center } \\
\text { boundary }\end{array}$ \\
\hline /famıli// & /phe:mtli:/ & family \\
\hline /ju:niti/ & /u:niTi:/ & unity \\
\hline /ma:kit/ & /ma:rkeT/ & market \\
\hline & $\overline{l n t l i \cdot c \cdot \bar{c} \cdot \breve{S} a n}$ & shopping \\
\hline /paust pfis/ & /po:st a:phis/ & $\begin{array}{l}\text { police station } \\
\text { post office }\end{array}$ \\
\hline /a:mi kamp/ & /a:rmi: kamp/ & army camp \\
\hline /sə:vIS steIf(ə)n/ & /sarvis sTe:Šan/ & service station \\
\hline /sa:vis/ & /sərvis/ & service \\
\hline /ləơn/ & & loan \\
\hline /lnIs(ə)ns/ & /la:san/ & license \\
\hline /kitfin/ & /kičan/ & kitchen \\
\hline /ba:Өrom/ & /ba:thru:m/ & bathroom \\
\hline /torlit// & /Ta:leT/ & toilet \\
\hline /bedrom/ & & bedroom \\
\hline /bildin/ & & building \\
\hline /ع:po:t/ & /ayarpo:T/ & airport \\
\hline /harweI/ & & highway \\
\hline /b $\Delta$ s stpp/ & & bus stop \\
\hline /rommeit/ & & $\begin{array}{l}\text { roommate } \\
\text { gas cylinder }\end{array}$ \\
\hline $\begin{array}{l}\text { lgas silinda/ } \\
\text { /rum hi:tə/ }\end{array}$ & $\begin{array}{l}\text { /ge:s silenDer/ } \\
\text { /ru:m hi:Tar/ }\end{array}$ & $\begin{array}{l}\text { gas cylinder } \\
\text { room heater }\end{array}$ \\
\hline /wə:kfop/ & /vərtkŠa:p/ & workshop \\
\hline /mat $5 \mathrm{in} /$ & /me:čin/ & matching \\
\hline /pa:tnə $\int \mathrm{rp} /$ & /pa:TnarŠip/ & partnership \\
\hline /Intəvju:/ & /inTarvu:/ & interview \\
\hline /mesidz/ & /mase:j/ & message \\
\hline
\end{tabular}

\section{H. Names of the Months of the Year}

In addition to the above-mentioned socio-cultural domains of Kashmiri speech community, Kashmiri speakers use purely English names for the months of the year. Although Kashmiri has developed its traditional set of names for all these months in Kashmiri, the speakers of the Kashmiri speech community extensively use English calendar names of moths of the year in their speech. On account of huge amount of the impact of English on the speech of Kashmiri speakers, the younger educated generation of Kashmiri speakers are totally unfamiliar with the traditional Kashmiri names of the months of the year. As a matter of fact, they feel more comfortable to name these months in English than in Kashmiri. It should be pointed out that the names of only a few of these months are used in their original form as in English, and those of others have been modified and naturalized by Kashmiri speakers in accordance with the phonetic temperament of their mother tongue.

TABLE 8

NAMES OF THE MONTHS OF YEAR

\begin{tabular}{|c|c|c|}
\hline Name of months in English & Naturalized in Kashmiri & Gloss \\
\hline /dzanjo(ə)ri/ & /janvəri:/ & january \\
\hline /februəri/ & /pharvəri:/ & february \\
\hline /ma:tf/ & /ma:rtči/ & march \\
\hline /eipr(I)1/ & /apre:1/ & april \\
\hline /meI/ & /məyi:/ & may \\
\hline /dzu:n/ & /ju:n/ & june \\
\hline /dzo'l $1 \Lambda \mathrm{I} /$ & /jUli:/ & july \\
\hline$/ \mathrm{o}: \mathrm{g} \Lambda \mathrm{st} /$ & /agast/ & august \\
\hline /sep'tembə/ & /satambar/ & september \\
\hline /pk'təobə/ & /aktu:bar/ & october \\
\hline /nə(U)'vembə/ & /navambar/ & november \\
\hline /di'scmbə/ & /dasambar/ & december \\
\hline
\end{tabular}




\section{CONCLUSION}

Being a language of wider communication and lingua franca, English has crossed the boundaries of its actual use and is now used in far-flung areas across the speech communities of the world. Like other speech communities of the world, Kashmiri speech community couldn't afford to be an exception to have English as one of its most significant contact languages .Since the language contact situation is a pre-requisite and for linguistic merger, the situation of linguistic amalgam in a certain social setup in turn is a remarkable trait of inter-lingual contact. Being a very prestigious language among Kashmiri speakers, English has emerged out to be a significant contact language among them. In EnglishKashmiri language amalgamation situation, Kashmiri is found to be enormously filled with English lexicon. The English lexicon that has been imported by Kashmiri is tremendously used by Kashmiri speakers in various domains of their social life. Much the same Kashmiri has been cordial and congenial to receive all this vocabulary treasure from English, English in response has impartially been found to be liberal, generous, and friendly in transporting this linguistic stock to Kashmiri during the course of contact.

Speakers of the Kashmiri language encounter English lexicon in almost each and every domain of their social sphere. These domains of their social life especially include: administration, medicine, information technology, education, language and literature, legal law and the domain of daily conversation. Moreover, the names of the months of the year used by Kashmiri speakers are imported from English. The flow of English words into Kashmir has been so extensive that not a single domain of their social life could afford to be an exception to their import.

Generally, it is the dominance of one linguistic system over the other which is considered as the main factor behind the import and export of linguistic items between them. But, in case of diffusion of linguistic items from English into Kashmiri, it is basically the power of media which has been found to be a strong driving force behind this word transfer (English into Kashmiri) at such a large scale. It should be pointed out that in English-Kashmiri linguistic diffusion, a lack of equivalence in the exchange of linguistic items has been found to a large extent. English has exported an extremely huge amount of lexicon to Kashmiri, whereas, not a single Kashmiri word has been found to make its way into English in return. This import of English words and concepts related to various domains of the social life of the Kashmiri speech community became an integral lexical necessity for the survival of the Kashmiri language.

To sum up, it can be reasonably argued that Kashmiri has imported and assimilated an immensely huge number of words of the English origin. Some of these words are slightly modified, integrated, domesticated and naturalized in accordance with phonetic temperament of the Kashmiri language. As a matter of fact, this study is limited in scope in the sense that it is a very simple effort to account for the transfer of an enormous number of words of the English origin into Kashmiri that the Kashmiri speakers use only during the course of their intra-group and intergroup oral communication. Therefore, in order to take a complete account of the transfer of English lexicon as loanwords into the Kashmiri, there is of course still a vast scope for further research to be carried out in this direction.

\section{ACKNOWLEDGEMENTS}

The authors extend their appreciation to the Deanship of Scientific Research at King Khalid University for funding this work under Research grant award number RGP.1/370/42.

\section{REFERENCES}

[1] Allyn and Bacon. (2009). New New Media. Penguin Academic Series. Vol. XIV, ISBN 978-0205673308. Boston, Massachusetts USA.

[2] Bloomfield. (1933). Language. New York: Holt, Rinehart and Winston.

[3] Brendan, T. O’Connor. (2014). Statistical Text Analysis for Social Science. University of Massachusetts Amhers, USA.

[4] Dozier et al. (2011). Principles of Community Engagement. NIH Publication No. 11-7782 Printed. University of California.

[5] Hall, E.T. (1977). The Silent Language. New York: Doubleday \& Company.

[6] Haugen, E (1950). The analysis of linguistic borrowing. Language. 26.2. pp.210-231. University of Wisconsin-Madison, USA.

[7] Heller, M. (1998). Codeswitching p.15. Berlin: Mouton deGruyter.

[8] Hoffer, B.L. (2002). Language Borrowing and Language Diffusion: an Overview. Intercultural Communication Studies XI-2, pp.1-36. Evora, Portugal: University of Evora.

[9] Hoffer, B.L. (1997). Borrowing at arm's length: Japanese borrowings from English. In Werner Mäder, Wolfgang Wölck, and Peter Weber, eds. Current Research in Contact Linguistics. Brussels, Belgium: Research Centre on Multilingualism.

[10] Koka, N.A. (2016). Sociolinguistic Perspectives of the Language Contact Situation and the Development of a Common Lexicon in Kashmiri-Urdu. In Indian Language Review: International Journal of Linguistics, ISSN: 2350 - 1057) Volume 2, No. 1: January 2016-June 2016, (pp. 21-47). New Delhi, India.

[11] Koka, N.A. (2015). Cross-cultural Communication and subsequent Diffusion of Loanwords: A case of Arabic-Kashmiri Linguistic Borrowing. In King Khalid University Journal of Humanities (Deposit No. 1435/3076), ISSN: 1658- 6727), Volume 24, No. 3,2015 A.D-1436 A.H (pp.127-150).King Khalid University Abha, KSA.

[12] Labov, W. (1966). Social Stratification of English in New York City. Washington: Centre for Applied Linguistics.

[13] Lehmann,W.P. (1962). Historical Linguistics: an Introduction p.1. New York; Holt..Rinehart and Winston.

[14] Poplack,S. (1988). Contrasting patterns of codeswitching and transfer. p 220. In M.Heller (eds.) Codeswitching. Berlin: Mouton deGruyter. 
[15] Robert Fine and Sam Feist. (2006). Social Media: Case Studies, Stories, and Perspectives. Yorkshire Publishers. New York USA.

[16] Sapir, E. (1921). Language. New York: Harcourt, Brace \& World.

[17] Scotton, C. (1988). Code-switching as indexical of social negotiations. In M.Heller (eds.) Codeswitching. Berlin: Mouton deGruyter.

[18] Weinreich, U. (1953). Languages in Contact. The Hague: Mouton \& Company.

Nisar Ahmad Koka, being highly motivated in carrying out teaching and research in the field of linguistics, did his M.A. and Ph.D. in Theoretical and Sociolinguistics Linguistics from Aligarh Muslim University Aligarh, India in 1998 and 2002 respectively. $\mathrm{He}$ has been engaged in teaching linguistics /applied linguistics and English as a Foreign Language (EFL) in different universities/institutions for the last 20 years or so. Dr. Koka has published around a dozen of research articles on Linguistics and language teaching in different national and international journals, and has also presented several papers in various conferences/seminars covering various themes and topics concerning linguistics and language teaching. He has also co-authored 3 books on 'Testing and Evaluation' in Indian Languages while working as junior resource person on the projects of Multipurpose Indian Language Evaluation System (MILES) and National Testing Service (NTS) India. Dr. Koka is currently engaged as an assistant professor at the Department of English, Faculty of Languages and Translation, King Khalid University Abha, KSA teaching English as Foreign Language (EFL).

Mohammed Nurul Islam (Ph.D) is an assistant professor in the Department of English, Faculty of Languages and Translations, King Khalid University, Kingdom of Saudi Arabia Since 2009. His areas of interest include ELT, ESP and World English. THEORY AND PRACTICE IN LANGUAGE STUDIES.

Mohammed Osman did his PhD in Literature from Dr. B. A Marathwada University of India in Literature. He did his B A from Mumbai University and M A from Dr B.A Marathwada University of India. He has been teaching English at King Khaled University for last seven years. He has been involved in teaching Grammar, Writing, and Reading. He is in charge King Khalid University department of Language and Translation Examination committee. He has interest in research in the field of linguistic, autobiographies and short stories in literature.

Javed Ahmad is a lecturer at English Language Center, King Khalid University, Abha, the Kingdom of Saudi Arabia. He joined the university as a lecturer in the session 2007-2008 and since then he is continuing his job. Currently, he is serving the English Language Center as a Campus Coordinator (Al-Graiger Campus).He received an MA (English Language and Literature) degree from Aligarh Muslim University, Aligarh, India. He also did his M. Ed. (Master in Education) from the same university. 